\title{
KESAN UMUR RELATIF TERHADAP PEMAIN BOLA JARING MSSM, SUKMA DAN KEBANGSAAN DI MALAYSIA
}

\author{
Norsaleha Mohd Ariffin, Muhamusyarrifa Hashim, Jeffrey F.L. Low \\ Fakulti Sains Sukan dan Kejurulatihan, Universiti Pendidikan Sultan Idris, Tg Malim, \\ Perak, Malaysia \\ Jurnal Sains Sukan dan Pendidikan Jasmani 8(1) 22-30, Received: 07 Mei 2019, Accepted: \\ 03 Jun 2019 \\ DOI: https://doi.org/10.37134/jsspj.vol8.1.3.2019

\begin{abstract}
Abstrak
Kajian ini bertujuan untuk menyelidik kesan umur relatif dalam kalangan atlet bola jaring Malaysia dalam kejohanan MSSM, SUKMA dan Kebangsaan. Seramai 691 orang (B12 (n=180); B15 (n=156); B18 (n=180); SUKMA $(n=132)$ dan kejohanan kebangsaan $(n=122)$ dipilih sebagai responden kajian. Tarikh lahir mereka dikumpul mengikut suku tahun dan taburan dianalisis dengan ujian Khi Kuasa Dua $\left(\chi^{2}\right)$. Kajian mendapati bahawa terdapat kesan umur relatif terhadap semua kategori atlet bola jaring yang mana atlet yang dilahirkan pada awal tahun adalah lebih ramai berbanding hujung tahun. Secara keseluruhan, atlet yang lahir pada suku tahun pertama (Januari ke Mac) adalah 3.6 kali ganda dari bilangan atlet yang lahir pada suku tahun keempat (Oktober ke Disember). Kajian ini mencadangkan atlet bola jaring dipilih berdasarkan kelebihan saiz fizikal kerana kematangan biologi untuk kategori bawah 12 dan 15 tahun sementara untuk kategori 18 tahun ke atas, pemilihan mereka adalah berdasarkan pengalaman dari kualiti latihan dan peluang bertanding yang lebih semasa usia muda. Ketidakseimbangan ini harus diteliti oleh pihak yang bertanggungjawab dalam pembangunan sukan bola jaring. Jurulatih perlu memahami kesan umur relatif agar tidak meminggirkan atlet yang lebih muda secara relatif dan memilih atlet berdasarkan kemahiran teknik dan taktik sukan tersebut.
\end{abstract}

Kata kunci: kesan umur relatif, atlet bola jaring, kematangan, saiz fizikal, pengalaman 


\title{
RELATIVE AGE EFFECTS ON MSSM, SUKMA AND NATIONAL NETBALL PLAYERS IN MALAYSIA
}

\begin{abstract}
This study aimed to investigate the relative age effects among the netball players in MSSM, SUKMA and national seniors' competitions in Malaysia. Date of birth of 691 netball players from the respective categories (180 players under 12s; 156 players under 15s; 180 players under 18s; 132 players SUKMA and 122 national seniors were collated and analyzed according to birth month quartiles. Non parametric test using chi-squared test $\chi^{2}$ showed significant differences for all ages and categories. The number of athletes born in the first quarter (January to March) was 3.6 times more than athletes born in the fourth quarter (October to December). This study suggests that the relatively older netball players in the under 12 and 15 age groups were selected more for their height due to early biological maturation whilst the older age groups were selected based on the vast experience accumulated from better coaching quality and more competitions from young. This imbalanced representation must be addressed by the authorities responsible in developing the sport. Coaches should be aware of the relative age effects in order not to overlook the relative younger players and select players based on technical and tactical skills rather than solely on physical attributes.
\end{abstract}

Keywords: relative age effect, netball players, biological maturation, physique, experience

\section{PENGENALAN}

Kebiasaannya, acara sukan berpasukan dikelaskan mengikut kategori umur berdasarkan tarikh kelayakan (competition cut-off date) yang tertentu (Baker, Schorer, Cobley, Brautigam, \& Busch, 2009). Kesannya, atlet remaja yang lebih muda dilihat terpaksa bersaing dengan atlet remaja yang lebih berusia secara relatif (Delorme, Chalabaev \& Raspaud, 2011). Sebagai contoh, seorang atlet yang lahir pada bulan Januari tahun 2007 dan seorang atlet lagi yang lahir pada bulan Disember tahun yang sama layak bertanding dalam kejohanan bawah umur 12 tahun MSSM 2019. Namun begitu, atlet yang lahir pada bulan Januari adalah lebih tua 11 bulan dari atlet yang lahir pada bulan Disember dan kedua mereka akan bertanding dalam pertandingan yang sama (Arrieta, Torres-Unda, Gil \& Irazusta, 2016). Fenomena tersebut dikenali sebagai kesan umur relatif. Kesan umur relatif (KUR) dapat didefinisikan sebagai perbandingan umur individu dengan rakan - rakannya yang dilahirkan dalam kalendar tahun yang sama (Gil, Badiola, Bidaurrazaga-Letona, Zabala-Lili, Gravina, SantosConcejero, Lekue \& Granados, 2014). Secara tidak langsung, fenomena kesan umur relatif juga dilihat mempengaruhi jurulatih untuk memilih atlet yang lebih tua secara relatif mewakili sesebuah pasukan (Okazaki, Keller, Fontana \& Gallagher, 2011).

Kajian KUR telah memberi tumpuan terhadap atlet lelaki iaitu bola sepak (Cobley, Schorer \& Baker, 2012), besbol (Nakata \& Sakamoto, 2011), dan bola keranjang (Torres-Unda, Zarrazquin, Gravina, Zubero, Seco, Gil, Gil, Irazusta, 2016). Hasil kajian - kajian tersebut menunjukkan bahawa atlet yang dilahirkan pada awal tahun adalah lebih ramai berbanding atlet yang dilahirkan pada hujung tahun. Sebagai contoh kajian terkini terhadap sepuluh liga terbaik bola sepak profesional lelaki yang menyertai Persatuan Bola Sepak Eropah (UEFA) mempunyai persamaan dengan kajian - kajian di atas yang mana atlet yang dilahirkan pada awal tahun adalah lebih ramai berbanding atlet yang dilahirkan pada hujung tahun (Yague, Rubia, Sanchez-Molina \& Molenero, 2018). Dapatan kajian ke atas atlet yang dilahirkan pada awal tahun juga menujukkan kelebihan dari psikologi (lebih yakin dan lebih bermotivasi) berbanding atlet yang lebih muda secara relatif. Gomez-Lopez, Sanchez, Gallego dan Rios (2017) menyatakan bahawa atlet yang dilahirkan pada hujung tahun adalah lebih cenderung untuk tidak bermotivasi dan tercicir dari penyertaan sukan dengan lebih awal.

Faktor kelebihan saiz fizikal dan mungkin fisiologikal (lebih tinggi dan lebih kuat) merupakan antara kriteria yang diperlukan oleh atlet untuk menyertai sesebuah pasukan. Secara relatifnya, atlet yang dilahirkan pada awal tahun adalah lebih tinggi dan lebih kuat berbanding atlet yang dilahirkan pada hujung tahun (Cobley, Baker Wattie \& McKenna, 2009). Namun, kanak - kanak yang dilahirkan pada hujung tahun dilihat sukar untuk menonjolkan diri kerana mempunyai saiz tubuh yang lebih 
kecil, kurang kuasa dan kekuatan berbanding kanak - kanak yang dilahirkan pada awal tahun (Malina, Baouchard \& Bar-Or, 2004). Situasi tersebut dapat dilihat ketika fasa awal perkembangan bagi atlet remaja yang mana permulaan proses tumbesaran remaja perempuan adalah berumur 10 tahun atau 11 tahun dan memuncak pada umur 12 atau 13 tahun apabila mencapai akil baligh dan berhenti ketika umur 18 tahun atau 19 tahun (Malina et al., 2004). Oleh itu, peningkatan jisim otot dan tahap kekuatan bagi kanak - kanak lelaki yang telah mencapai kematangan dengan lebih awal dilihat lebih berjaya dalam aktiviti sukan (Malina et al., 2004). Ini dapat dilihat melalui kajian yang dijalankan terhadap pemain ragbi (Till, Cobley, Wattie, O'Hara, Cooke, \& Chapman, 2010). Terdapat kesan umur relatif terhadap atlet ragbi lelaki dalam semua kategori lelaki iaitu bawah 12, bawah 14, bawah 16 dan ke peringkat seterusnya berbanding atlet wanita yang hanya wujud dalam kategori 12 tahun. Kewujudan kesan umur relatif bagi kategori bawah 12 adalah disebabkan oleh usia remaja wanita mengalami haid pertama merupakan petunjuk terbaik terhadap kematangan seksual dalam melihat perkembangan serta prestasi seseorang (Malina, 1996).

Secara umumnya, disiplin sukan wanita hanya memerlukan keupayaan yang sedikit berbanding sukan lelaki dan faktor kematangan bukanlah penentu kepada keupayaan tersebut (Raschner, Muller \& Hildebrandt, 2012). Pencarian literatur mendapati bahawa kajian mengenai kesan umur relatif terhadap atlet wanita adalah kurang. Sebagai contoh, sukan bola tampar (Nakata \& Sakamoto, 2011), bola sepak wanita (Sedano, Vaeyens \& Redondo, 2015) dan ragbi (Till et al., 2010). Hasil kajian - kajian yang dinyatakan tersebut mendapati bahawa terdapat kesan umur relatif bagi atlet wanita. Namun, kajian yang dijalankan oleh Honert (2012) terhadap pemain bola sepak wanita Australia mendapati bahawa tidak terdapat kesan umur relatif berikutan kurang persaingan sengit dalam kalangan wanita berbanding lelaki. Bola jaring merupakan salah satu sukan berpasukan wanita yang menekankan ciri - ciri kecergasan fizikal seperti kekuatan, kuasa, kelajuan dan ketangkasan untuk atlet meraih kejayaan (Taylor, Bonetti, Tanner, Tanner \& Gore, 2013). Oleh itu, pasukan yang mempunyai atlet yang lebih tua secara relatif akan menunjukkan prestasi yang lebih baik dan bermain dalam tempoh masa yang lebih lama berbanding atlet yang lebih muda dalam semua perlawanan (Arrieta et al., 2016). Namun, setiap individu mempunyai tahap kecergasan fizikal dan ciri - ciri antopometrik yang berbeza seperti faktor ketinggian dan berat badan. Dalam sukan bola jaring, faktor ketinggian merupakan salah satu kelebihan bagi atlet untuk melakukan jaringan. Kebiasaannya, pemain yang lebih tinggi akan mempunyai kelebihan untuk bermain sukan tersebut (Arrieta et al., 2016). Secara tidak langsung, atlet yang lebih rendah secara fizikal mempunyai kesukaran untuk melakukan halangan terhadap penjaring (Arias, 2012).

Berdasarkan dapatan kajian - kajian yang dilakukan terhadap sukan wanita, kewujudan kesan umur relatif didapati tidak konsisten. Tambahan pula, tiada kajian mengenai kesan umur relatif terhadap pemain sukan bola jaring di Malaysia. Oleh itu, kajian ini dijalankan adalah untuk mengkaji sama ada kesan umur relatif wujud dalam pemilihan atlet bola jaring. Komposisi peserta kajian ini meliputi semua peringkat umur iaitu bawah 12, 15, 18 (MSSM), bawah 21 (SUKMA) dan atlet dewasa (Kejohanan Kebangsaan). Adalah diharapkan dengan menyelidik pemain bola jaring secara merentas (cross-sectional), ia dapat memberi gambaran yang menyeluruh tentang kesan umur relatif dalam kalangan atlet bola jaring di Malaysia. Daripada dapatan kajian-kajian lepas, hipotesis kajian ini menjangkakan bahawa tidak terdapat kesan umur relatif terhadap atlet bola jaring di Malaysia.

\section{KAEDAH}

\section{Peserta}

Seramai 691 orang pemain menyertai kejohanan bola jaring MSSM, SUKMA dan kejohanan kebangsaan pada tahun 2018 terlibat dalam kajian ini. Peserta kajian adalah terdiri daripada pemain-pemain bola jaring yang mewakili negeri masing-masing dalam kejohanan tersebut. Rekabentuk kajian ini adalah berbentuk diskriptif. Peserta kajian ini terdiri dari pemain bola jaring bawah 12 tahun $(\mathrm{n}=180)$, bawah $15(\mathrm{n}=156)$ bawah 18 tahun $(\mathrm{n}=180)$ dan SUKMA $(\mathrm{n}=132)$ dan kejohanan kebangsaan $(\mathrm{n}=122)$. 


\section{Prosedur}

Data pasukan bola jaring bagi peringkat MSSM dan SUKMA di ambil menerusi portal rasmi MSSM dan https://sukma2018.perak.gov.my/index.php/info/pengenalan-sukma-2018 masing-masing. Data pasukan bola jaring yang bertanding dalam kejohanan kebangsaan diperolehi melalui Persatuan Bola Jaring Malaysia. Tarikh lahir peserta diagihkan mengikut suku tahun (kuartil) bulan kelahiran masingmasing. Tarikh kelahiran atlet diagihkan kepada empat kuartil (K), iaitu kuartil 1 = Januari, Februari, Mac; kuartil 2 = April, Mei, Jun; kuartil 3 = Julai, Ogos, September; kuartil $4=$ Oktober, November, Disember. Prosedur ini adalah mengikut kajian-kajian lepas seperti Arrieta et al., (2016) dan Torres-Unda et al., (2016). Atlet bola jaring juga diagihkan mengikut kategori umur pemain iaitu bawah 12 tahun, bawah 15 tahun, bawah 18 tahun, bawah 21 tahun dan dewasa.

\section{Analisis Statistik}

Bulan kelahiran peserta dianalisis menggunakan Ujian Khi Kuasa Dua $\left(\chi^{2}\right)$ dengan nilai signifikan ditetapkan pada aras .05 dalam semua analisis. Peserta dikategorikan kepada beberapa kuartil mengikut bulan kelahiran selepas tarikh permulaan musim persekolahan di Malaysia iaitu 1 Januari. Semua data akan dikumpul dan dianalisis dengan menggunakan perisian Statistical Package for The Social Sciences (SPSS) versi 23.0. Ujian statistik bukan parametrik Khi Kuasa Dua diguna untuk menilai taburan bilangan peserta kajian yang dilahirkan mengikut suku tahun yang ditetapkan dengan taburan populasi kelahiran di Malaysia yang dianggap sebagai sama rata mengikut setiap suku tahun. Sekiranya ujian Khi Kuasa Dua menunjukkan nilai signifikan, ujian post-hoc Standard Residual digunakan untuk menentukan kuartil mana yang berbeza secara signifikan. Nilai Standard Residual ialah \pm 1.96 .

\section{DAPATAN KAJIAN}

Rajah 1.1 menunjukkan taburan agihan bilangan keseluruhan atlet bola jaring mengikut kuartil. Bilangan atlet yang dilahirkan pada dua kuartil pertama adalah lebih ramai berbanding dua kuartil terakhir bagi atlet bola jaring.

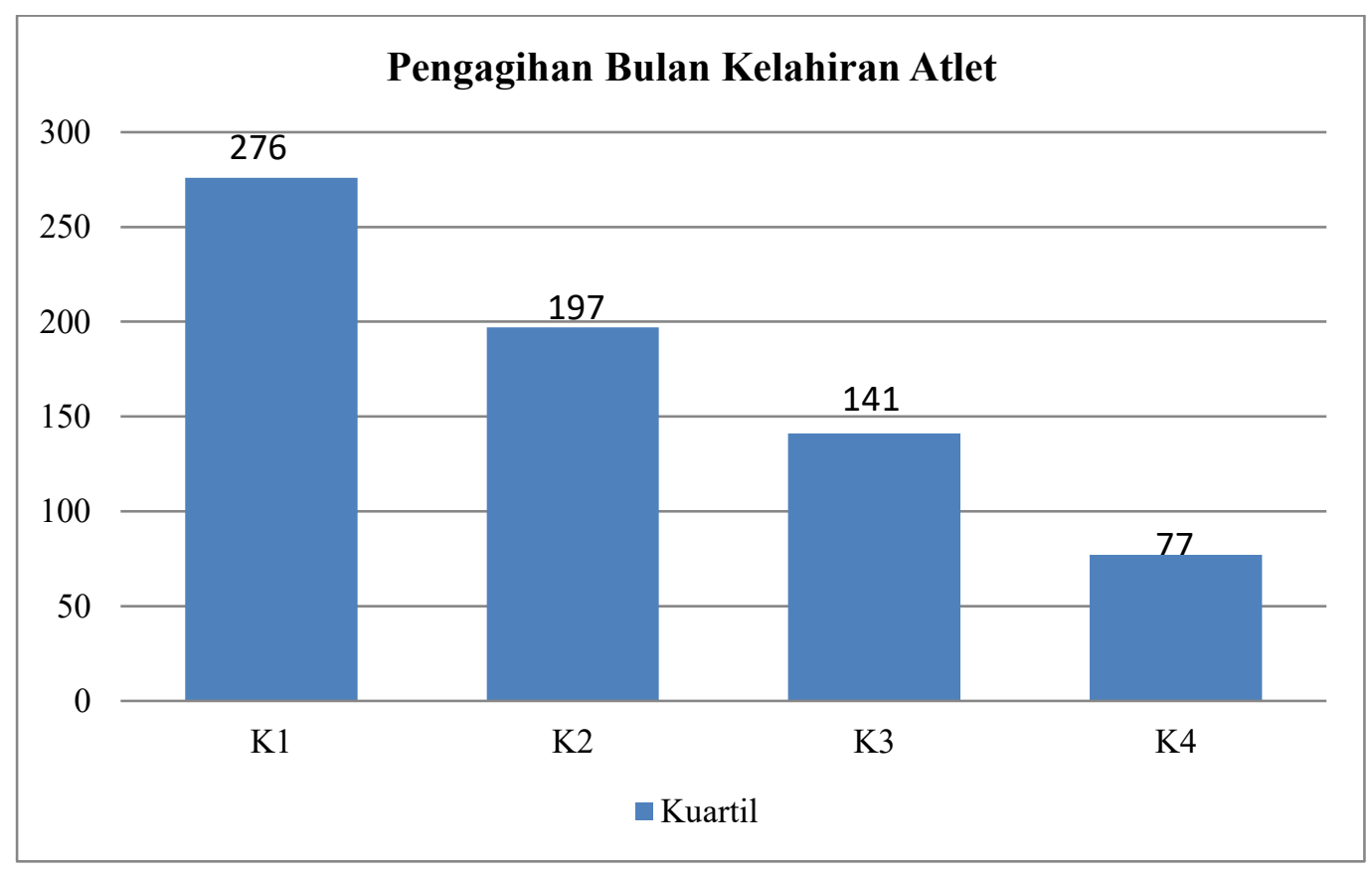

Rajah 1.1 Taburan agihan bilangan keseluruhan atlet bola jaring mengikut kuartil. 
Secara keseluruhanya, terdapat kesan umur relatif terhadap atlet bola jaring di Malaysia. $\chi^{2}(3, n=$ $691)=124.02 ; p<.001$. Bilangan pemain yang dilahirkan pada kuartil pertama (K1) adalah jauh lebih ramai berbanding kuartil - kuartil yang lain. Seramai 276 (39.9\%) orang atlet dilahirkan pada K1 diikuti dengan bilangan pemain yang dilahirkan pada kuartil kedua (K2) $(\mathrm{n}=197,28.5 \%)$. Bilangan atlet yang dilahirkan pada kuartil ketiga (K3) adalah seramai 141 (20.4\%) orang manakala, bilangan atlet yang paling kurang iaitu seramai 77 (11.1\%) orang yang dilahirkan pada kuartil keempat (K4). Bilangan pemain yang dilahirkan pada $\mathrm{K} 1$ adalah 3.6 kali lebih ramai daripada bilangan pemain yang dilahirkan pada $\mathrm{K} 4$.

Rajah 1.2 menunjukkan taburan bilangan atlet bola jaring mengikut suku tahun dan mengikut kumpulan umur. Kesan umur relatif dapat dilihat bagi semua kategori atlet bola jaring Malaysia.

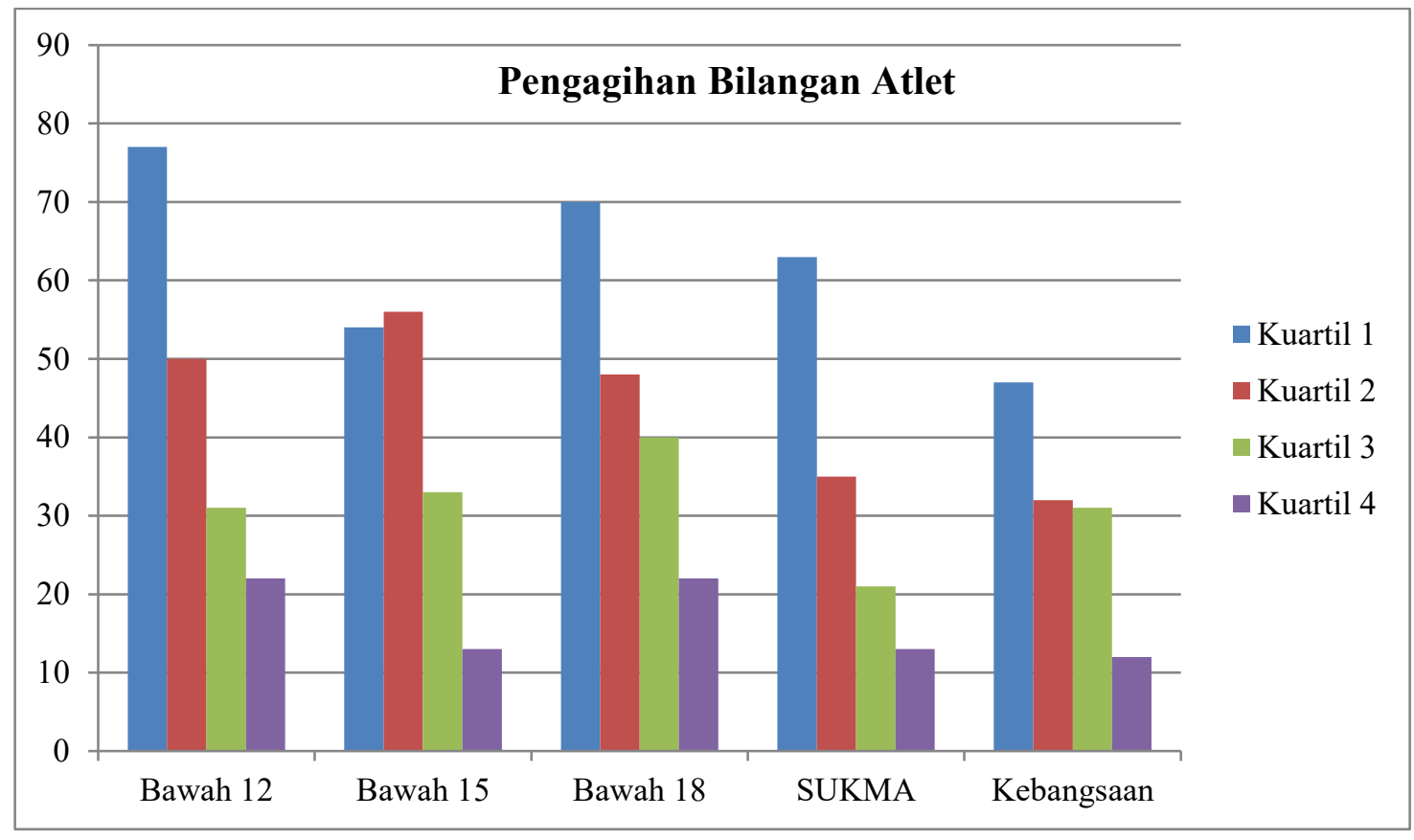

Rajah 1.2 Taburan bilangan pemain bola jaring mengikut suku tahun dan mengikut kumpulan umur.

Jadual 1.3 pula menunjukkan analisis statistik untuk taburan bilangan atlet mengikut kategori umur dan mengikut kuartil. Terdapat kesan umur relatif dalam semua kategori yang mana atlet yang dilahirkan pada awal tahun adalah lebih ramai berbanding atlet yang dilahirkan pada hujung tahun. 
Kesan Umur Relatif Terhadap Pemain Bola Jaring MSSM, Sukma Dan Kebangsaan Di Malaysia

Taburan agihan bilangan semua atlet bawah 12, bawah 15, bawah 18, SUKMA dan Kebangsaan

\begin{tabular}{|c|c|c|c|c|c|c|c|c|c|c|c|}
\hline Kategori & K1 & $\mathrm{K} 2$ & K3 & K4 & Jum & $\chi^{2}$ & Sig & \multicolumn{4}{|c|}{ SR } \\
\hline & Jan-Mac & Apr-Jun & Jul-Sept & Okt-Dis & & & $P$. & K1 & $\mathrm{K} 2$ & K3 & K4 \\
\hline B12 & $\begin{array}{l}77 \\
(42.8 \%)\end{array}$ & $\begin{array}{c}50 \\
(27.8 \%)\end{array}$ & $\begin{array}{c}31 \\
(17.2 \%)\end{array}$ & $\begin{array}{c}22 \\
(12.2 \%)\end{array}$ & 180 & 39.4 & .001 & $4.77 *$ & 0.75 & $-2.09 *$ & $-3.43 *$ \\
\hline B15 & $\begin{array}{l}54 \\
(34.6 \%)\end{array}$ & $\begin{array}{c}56 \\
(35.9 \%)\end{array}$ & $\begin{array}{c}33 \\
(21.1 \%)\end{array}$ & $\begin{array}{r}13 \\
(8.3 \%)\end{array}$ & 156 & 31.4 & .001 & $2.40 *$ & $2.72 *$ & -0.96 & $-4.16^{*}$ \\
\hline B18 & $\begin{array}{l}70 \\
(38.9 \%)\end{array}$ & $\begin{array}{c}48 \\
(26.7 \%)\end{array}$ & $\begin{array}{c}40 \\
(22.2 \%)\end{array}$ & $\begin{array}{c}22 \\
(12.2 \%)\end{array}$ & 180 & 26.4 & .001 & $3.73 *$ & 0.45 & -0.75 & $-3.43 *$ \\
\hline SUKMA & $\begin{array}{l}63 \\
(47.7 \%)\end{array}$ & $\begin{array}{c}35 \\
(26.5 \%)\end{array}$ & $\begin{array}{c}21 \\
(15.9 \%)\end{array}$ & $\begin{array}{r}13 \\
(9.9 \%)\end{array}$ & 132 & 43.9 & .001 & $2.68 *$ & -1.49 & $-3.58 *$ & $-4.77 *$ \\
\hline Kebangsaan & $\begin{array}{l}47 \\
(38.5 \%)\end{array}$ & $\begin{array}{c}32 \\
(26.2 \%)\end{array}$ & $\begin{array}{c}31 \\
(25.4 \%)\end{array}$ & $\begin{array}{r}12 \\
(9.8 \%)\end{array}$ & 122 & 20.23 & .001 & $2.99 *$ & 0.27 & 0.09 & $-3.35^{*}$ \\
\hline
\end{tabular}

Jadual 1.3 menunjukkan analisis statistik untuk taburan bilangan atlet mengikut kategori umur dan mengikut kuartil. 
Analisis kesan umur relatif semua atlet bola jaring di Malaysia menunjukkan terdapat kesan umur relatif $\chi^{2}(3, \mathrm{~N}=691)=124.02, \mathrm{p}<0.001$. Bilangan dan peratus bagi kategori bawah 12 mengikut kuartil adalah $\mathrm{K} 1=77(42.8 \%), \mathrm{K} 2=50(27.8 \%), \mathrm{K} 3=31(17.2 \%)$ dan $\mathrm{K} 4=22(12.2 \%)$. Analisis SR menunjukkan bilangan atlet yang lahir pada K1 $(\mathrm{SR}=4.77)$ adalah lebih secara signifikan berbanding kuartil - kuartil lain. Bilangan atlet yang dilahirkan pada $\mathrm{K} 3(\mathrm{SR}=-2.09)$ dan $\mathrm{K} 4(\mathrm{SR}=-3.43)$ adalah kurang secara signifikan daripada kuartil lain. Bagi kategori bawah 15, bilangan dan peratus atlet mengikut kuartil adalah $\mathrm{K} 1=54(34.6 \%), \mathrm{K} 2=56(35.9 \%), \mathrm{K} 3=33(21.2 \%)$ dan $\mathrm{K} 4=13(8.3 \%)$. Analisis SR menunjukkan bilangan atlet yang lahir pada K1 $(\mathrm{SR}=2.40)$ dan $\mathrm{K} 2(\mathrm{SR}=2.72)$ adalah lebih secara signifikan berbanding kuartil - kuartil lain sementara bilangan atlet yang dilahirkan pada $\mathrm{K} 4(\mathrm{SR}=-4.16)$ adalah kurang secara signifikan. Bagi kategori bawah 18, bilangan dan peratus atlet mengikut kuartil adalah $\mathrm{K} 1=70(38.9 \%), \mathrm{K} 2=48(26.7 \%), \mathrm{K} 3=40(22.2 \%)$ dan $\mathrm{K} 4=22(12.2 \%)$. \%). Analisis SR menunjukkan bilangan atlet yang lahir pada K1 $(\mathrm{SR}=3.73)$ adalah lebih secara signifikan berbanding kuartil - kuartil lain manakala bilangan atlet yang dilahirkan pada K4 (SR=-3.43) adalah kurang secara signifikan. Bagi kategori SUKMA, bilangan dan peratus atlet mengikut kuartil adalah $\mathrm{K} 1=63(47.7 \%), \mathrm{K} 2=35(26.5 \%), \mathrm{K} 3=21(15.9 \%)$ dan $\mathrm{K} 4=13$ (9.9\%). Analisis SR menunjukkan bilangan atlet yang lahir pada $\mathrm{K} 1(\mathrm{SR}=2.68)$ adalah lebih secara signifikan berbanding kuartil - kuartil lain manakala bilangan atlet yang dilahirkan pada K3 ( $\mathrm{SR}=-3.58)$ dan $\mathrm{K} 4(\mathrm{SR}=-4.77)$ adalah kurang secara signifikan. Bagi kategori kebangsaan, bilangan dan peratus atlet mengikut kuartil adalah $\mathrm{K} 1=47(38.5 \%), \mathrm{K} 2=32(26.2 \%), \mathrm{K} 3=31(25.4 \%)$ dan $\mathrm{K} 4=12(9.8 \%)$. Analisis SR menunjukkan bilangan atlet yang lahir pada K1 ( $\mathrm{SR}=2.99)$ adalah lebih secara signifikan berbanding kuartil - kuartil lain manakala bilangan atlet yang dilahirkan pada $\mathrm{K} 4(\mathrm{SR}=-3.35)$ adalah kurang secara signifikan daripada kuartil lain. Berdasarkan jadual 1.3 di atas, kesan umur relatif wujud dalam semua kategori atlet bola jaring di Malaysia. Setiap kategori di analisis secara berasingan dan menunjukkan bahawa terdapat kesan umur relatif dalam semua kategori yang mana atlet yang dilahirkan pada awal tahun adalah lebih ramai berbanding atlet yang dilahirkan pada hujung tahun.

\section{PERBINCANGAN}

Kajian ini bertujuan untuk mengkaji kewujudan kesan umur relatif dalam kalangan atlet bola jaring di Malaysia. Hipotesis yang menjangkakan bahawa tidak terdapat kesan umur relatif dalam kalangan atlet bola jaring Malaysia ditolak. Secara keseluruhannya, bilangan atlet yang dilahirkan pada K1 adalah jauh lebih ramai berbanding yang kuartil - kuartil lain iaitu seramai 276 orang atlet dan mempunyai nilai peratusan sebanyak $39.9 \%$. Oleh itu, berdasarkan hasil kajian tersebut jelaslah menunjukkan bahawa fenomena kesan umur relatif wujud dalam kalangan atlet bola jaring Malaysia dalam setiap kategori.

Pemilihan atlet bola jaring bagi kategori umur bawah 12 dan bawah 15 tahun adalah disebabkan oleh pertumbuhan fizikal atlet. Hasil kajian disokong oleh kajian berkaitan (Nakata \& Sakamoto, 2011; Sedano et al., 2015 dan Till et al., 2010) yang mana atlet dipilih berdasarkan kematangan fizikal. Ini menunjukkan bahawa kanak - kanak perempuan yang dilahirkan pada awal tahun mempunyai peluang yang lebih tinggi untuk dipilih mewakili sekolah atau negeri berbanding atlet yang dilahirkan pada hujung tahun. Oleh itu, kanak - kanak yang dilahirkan pada hujung tahun dilihat sukar untuk menonjolkan diri kerana saiz tubuh yang lebih kecil, kurang kuasa dan kekuatan berbanding kanak - kanak yang dilahirkan pada awal tahun (Malina et al., 2004). Tambahan pula, sukan bola jaring memberi penekankan terhadap aspek saiz dan kecergasan fizikal seperti ketinggian, kelajuan dan ketangkasan untuk atlet meraih kejayaan (Taylor et al., 2013).

Selain itu, pemilihan atlet bagi kategori bawah 18 tahun, SUKMA dan kebangsaan bukan lagi berdasarkan saiz fizikal. Ini kerana proses tumbesaran remaja perempuan terhenti dalam lingkungan umur 18 tahun atau 19 tahun (Malina et al., 2004). Justeru, tiada perbezaan yang ketara dari aspek fizikal bagi setiap atlet. Walaubagimana pun, kewujudan kesan umur relatif bagi kategori umur bawah 18 tahun, 
SUKMA dan kebangsaan adalah disebabkan oleh faktor persaingan yang tinggi. Hasil tersebut menyangkal kajian yang dilakukkan ke atas pemain bola sepak wanita Australia (Honert, 2012) yang mendapati bahawa tidak terdapat kesan umur relatif berikutan kurang persaingan sengit dalam kalangan wanita berbanding lelaki. Persaingan sengit berlaku disebabkan oleh faktor pengalaman yang cenderung dimiliki oleh atlet yang lebih tua. Kebiasaanya, atlet yang lebih tua mempunyai banyak pengalaman berbanding atlet yang lebih muda. Atlet yang lebih tua secara relatif berkemungkinan telah dipilih untuk memasuki sekolah sukan Malaysia atau negeri selepas umur 12 tahun dan seterusnya mendapat latihan yang lebih banyak dan berkualiti disamping menerima tunjuk ajar daripada jurulatih yang lebih berpengalaman. Atlet-atlet ini juga mungkin berpeluang menyertai lebih banyak pertandingan. Oleh itu, atlet yang dilahirkan pada awal tahun mempunyai peluang yang lebih tinggi untuk memperbaiki dan membangunkan kemahiran berbanding atlet yang dilahirkan pada hujung tahun dalam sesuatu sukan (Musch \& Grondin, 2001). Justeru, pasukan yang mempunyai atlet yang lebih tua secara relatif akan menunjukkan prestasi yang lebih baik dan bermain dalam tempoh masa yang lebih lama berbanding atlet yang lebih muda dalam semua perlawanan (Arrieta et al., 2016).

\section{KESIMPULAN}

Sebagai kesimpulan, kesan umur relatif dalam kalangan atlet bola jaring di Malaysia wujud dalam semua kategori yang mana atlet yang dilahirkan pada awal tahun adalah lebih ramai berbanding atlet yang dilahirkan pada hujung tahun. Fenomena ini sering berlaku ke atas sukan yang memerlukan keupayaan fizikal seperti kuasa, kekuatan dan kelajuan. Berkemungkinan ramai jurulatih yang mahukan jalan pintas dengan memilih atlet berdasarkan faktor fizikal sahaja untuk meraih kejayaan. Justeru, pihak yang terlibat dalam pemilihan atlet khususnya jurulatih perlu diberi pendedahan berkaitan kesan umur relatif supaya tidak meminggirkan atlet yang berkualiti dan berkemahiran tinggi dalam sukan. Ketidakseimbangan ini harus diteliti oleh pihak yang bertanggungjawab dalam pembangunan sukan bola jaring. Adalah diharapkan kajian pada masa akan datang dapat mengkaji fenomena kesan umur relatif terhadap sukan individu bagi atlet wanita di Malaysia berdasarkan posisi pemain, ukuran antopometrik dan prestasi pemain di Malaysia.

\section{RUJUKAN}

Arias, J. L. (2012). Performance as a function of shooting style in basketball players under 11 years of age. Perceptual and Motor Skills, 114(2), 446-456.

Arrieta, H., Torres-Unda, J., Gil, S. M., \& Irazusta, J. (2016). Relative age effect and performance in the U16, U18 and U20 European Basketball Championships. Journal of Sports Sciences, 34(16), 1530-1534.

Baker, J., Schorer, J., Cobley, S., Bräutigam, H., \& Büsch, D. (2009). Gender, depth of competition and relative age effects in team sports. Asian Journal of Exercise \& Sports Science, 6(1). 1-7.

Cobley, S., Baker, J., Wattie, N., \& McKenna, J. (2009). Annual age-grouping and athlete development. Sports Medicine, 39(3), 235-256.

Cobley, S., Schorer, J., \& Baker, J. (2012). Identification and development of sport talent: A brief Introduction to a growing field of research and practice. In Talent Identification and Development in Sport (pp. 21-30). Routledge.

Delorme, N., Chalabaev, A., \& Raspaud, M. (2011). Relative age is associated with sport dropout: evidence from youth categories of French basketball. Scandinavian Journal of Medicine \& Science in Sports, 21(1), 120-128.

Gil, S. M., Badiola, A., Bidaurrazaga-Letona, I., Zabala-Lili, J., Gravina, L., Santos-Concejero, J., ... \& Granados, C. (2014). Relationship between the relative age effect and anthropometry, maturity and performance in young soccer players. Journal of Sports Sciences, 32(5), 479-486.

Van den Honert, R. (2012). Evidence of the relative age effect in football in Australia. Journal of Sports Sciences, 30(13), 1365-1374. 
Gómez-López, M., Sánchez, S. A., Granero-Gallegos, A., \& Ríos, L. J. C. (2017). Relative age effect in handball players of Murcia: Influence of sex and category of game. Journal of Human Sport and Exercise, 12(3), 565-573.

Malina, R.M. (1996). The young athlete: Biological growth and maturation in a biocultural. In F.L. \& R.E Smith (Eds.) Children and youth in sport: A biopsychosocial prespective (161-186).

Madison: Brown and Benchmark

Malina, R. M., Bouchard, C., \& Bar-Or, O. (2004). Growth, maturation, and physical activity. Human kinetics.

Musch, J., \& Grondin, S. (2001). Unequal competition as an impediment to personal development: A review of the relative age effect in sport. Developmental review, 21(2), 147-167.

Nakata, H., \& Sakamoto, K. (2011). Relative age effect in Japanese male athletes. Perceptual and motor skills, 113(2), 570-574.

Okazaki, F. H., Keller, B., Fontana, F. E., \& Gallagher, J. D. (2011). The relative age effect among female Brazilian youth volleyball players. Research quarterly for exercise and sport, 82(1), 135-139.

Raschner, C., Müller, L., \& Hildebrandt, C. (2012). The role of a relative age effect in the first winter Youth Olympic Games in 2012. Br J Sports Med, 46(15), 1038-1043.

Sedano, S., Vaeyens, R., \& Redondo, J. C. (2015). The relative age effect in Spanish female soccer players. Influence of the competitive level and a playing position. Journal of human kinetics, 46(1), 129137.

Taylor, K. L., Bonetti, D. L., Tanner, R., Tanner, R., \& Gore, C. (2013). Netball players. Physiological tests for elite athletes $\left(2^{\text {nd }}\right.$ ed.). Lower Mitcham, South Australia: Human Kinetics

Till, K., Cobley, S., Wattie, N., O'Hara, J., Cooke, C., \& Chapman, C. (2010). The prevalence, influential factors and mechanisms of relative age effects in UK Rugby League. Scandinavian Journal of Medicine \& Science in Sports, 20(2), 320-329.

Torres-Unda, J., Zarrazquin, I., Gravina, L., Zubero, J., Seco, J., Gil, S. M., ... \& Irazusta, J. (2016). Basketball performance is related to maturity and relative age in elite adolescent players. The Journal of Strength \& Conditioning Research, 30(5), 1325-1332.

Yagüe, J. M., de la Rubia, A., Sánchez-Molina, J., Maroto-Izquierdo, S., \& Molinero, O. (2018). The relative age effect in the 10 best leagues of male professional football of the Union of European Football Associations (UEFA). Journal of Sports Science \& Medicine, 17(3), 409.

\section{Đ- Norsaleha Mohd Ariffin}

Fakulti Sains Sukan dan Kejurulatihan, Universiti Pendidikan Sultan Idris, Malaysia Email: norsalehaariffin@yahoo.com 